\title{
$B A A L C$ and ERG Expression in Egyptian Patients with Acute Myeloid Leukemia, Relation to Survival and Response to Treatment
}

\author{
Aml Soliman ${ }^{\star}$, Asmaa Abdel Aal, Reham Afify, Noha Ibrahim \\ Cairo University, Clinical Pathology, Cairo, Egypt
}

\begin{abstract}
Citation: Soliman A, Abdel Aal A, Afify R, Ibrahim N. $B A A L C$ and ERG Expression in Egyptian Patients with Acute Myeloid Leukemia, Relation to Survival and Response to Treatment. Open Access Maced J Med Sci. $2016 \quad$ Jun $\quad 15 ;(2): 264-270$.

Keywords: BAALC: ERG; gene expression; Quantitative real-time RT-PCR; AML

${ }^{\star}$ Correspondence: Aml S Nasr. Associate professor of Clinical pathology, Haematology Unit, Kasr El Eini Schoo of Medicine, Cairo University, Cairo, Egypt. E-mal: amlsoliman78@yahoo.com

Received: 10-Mar-2016; Revised: 16-Apr-2016; Accepted: 10-May-2016; Online first: 22-May-2016

Copyright: ๑ 2016 Aml Soliman, Asmaa Abdel Aal, Reham Afity, Noha lbrahim. This is an open-access article distributed under the terms of the Creative Commons Attribution License, which permits unrestricted use distribution, and reproduction in any medium, provided the original author and source are crediled.

Competing Interests: The authors have declared that no competing interests exis.
\end{abstract}

Abstract

AIM: Aim was to detect Brain and Acute Leukemia, Cytoplasmic (BAALC) and ETS-related gene $(E R G)$ expression in patients with acute myeloid leukemia (AML) as well as to study their biologic and prognostic impact on the disease outcome and survival.

PATIENTS AND METHODS: The current study was carried out on 44 patients with denovo acute myeloid leukemia, as well as 44 age and sex matched controls. The quantitative real-time reverse transcription-polymerase chain reaction (RT-PCR) assay was performed for estimation of BAALC and $E R G$ expression

RESULTS: The current study was carried out on 44 patients with denovo acute myeloid leukemia, as well as 44 age and sex matched controls. The quantitative real-time reverse transcriptionpolymerase chain reaction (RT-PCR) assay was performed for estimation of $B A A L C$ and $E R G$ expression. BAALC was expressed in $36(81.82 \%)$ of $A M L$ cases versus $10(22.72 \%)$ of the control group which was highly statistically significant $(P<0.001)$. While $E R G$ was positive in $39(88.64 \%)$ of cases and $8(18.18 \%)$ of controls and that was also highly statistically significant $(\mathrm{P}<0.001)$.

CONCLUSION: Further researches still needed to clarify the role of BAALC and ERG in the pathogenesis of leukemia and their importance as targets for treatment of AML.

\section{Introduction}

Acute myeloid leukemia (AML) is a heterogeneous disease with respect to clinical picture and therapeutic outcome, partly reflected by differences in molecular and cytogenetics [1-3].

Clonal cytogenetic abnormalities are one of the most important factors predicting clinical outcome in acute myeloid leukemia and are used to guide riskadapted treatment strategies [4-6]. Deregulated expression of genes coding transcription factors involved in cell proliferation, survival or differentiation is known to be implicated in the process of leukemogenesis [7-9]. Brain and acute leukemia, the cytoplasmic gene $(B A A L C)$ and ETS-related gene $(E R G)$ are examples of these transcription factors [1012].

The brain and acute leukemia, cytoplasmic (BAALC), which maps on chromosome 8 at $8 \mathrm{q} 22.3$, was originally observed in the neuroderm and its expression was reported as a hematopoietic precursor, such as the early hematopoietic cells of a cluster of differentiation 34+ [8]. BAALC expression was higher in bone marrow compared to blood. In addition, high levels of BAALC expression were present in leukemic blasts in subsets of acute lymphoblastic leukemia (ALL) and AML patients with a normal karyotype [13], it may act as an adverse prognostic factor through prompting proliferation and inhibiting apoptosis in leukemia cells [14]. 
$B A A L C$ gene is considered as a marker of early hematopoietic progenitor cells. High levels of $B A A L C$ expression were found in AML patients with trisomy 8 , as well as in a subset of cytogenetically normal -AML(CN-AML) patients in which it was considered as a poor prognostic factor $[15,16]$.The role of BAALC in leukemogenesis is not fully understood, but it was proposed that BAALC blocks myeloid differentiation [15].

$E R G$ gene, located on chromosome band 21q22, belongs to the ETS family of transcription factors required for normal hematopoiesis. $E R G$ plays an important role in early hematopoiesis and hematopoietic stem cell (HSC) maintenance [17].

It is a transforming proto-oncogene that is expressed in stem cells and endothelial cells. It is frequently overexpressed in AML patients with complex karyotypes and amplification of chromosome 21 [18].

The $E R G$ gene has been found to be involved in atypical chromosomal rearrangements with alterations of the transcription factor in several cancers. Aberrant expression of full-length $E R G$ protein has been found in acute myeloid leukemia and

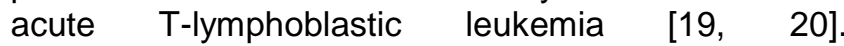
Chromosomal rearrangements driving the formation of $E W S / E R G$ and FUS/ERG fusion proteins have been described in a subset of Ewing sarcoma [21, 22] and in acute myeloid leukemia [23, 24]. In acute leukemia, high ERG mRNA expression levels are an independent prognostic factor. Studies have demonstrated that increased ERG expression is associated with poor prognosis in cytogenetically normal AML [25] and in adult T-ALL [10].

Most of the previous researches were concerned about levels and prognostic effect of $B A A L C$ and ERG in CN-AML patients while data about their incidence in AML and relation to cases with abnormal karyotype were lacking.

We sought to determine the prognostic impact of the expression of $B A A L C$ and $E R G$ in de novo $A M L$ patients.

The objective of this study was to detect the incidence of $B A A L C$ and $E R G$ in a group of denovo AML patients with abnormal karyotype in comparison to normal individuals, their levels and distribution among $A M L F A B$ subtypes as well as to study their impact on the disease outcome and reliability in detection of minimal residual disease in relation to the cytogenetic markers.

\section{Patients and Methods}

The current study was carried out on 44 patients with denovo acute myeloid leukemia (AML), in the period between, July 2011 and July 2012 among cases referred to nuclear medicine and oncology unit of Kasr Al Ainy School of medicine, Cairo University with follow-up period of 18 months, as well as 44 age and sex matched controls. They were patients suspected to have hypersplenism or idiopathic thrombocytopenia coming for BM aspirate. Cases were diagnosed according to WHO criteria [25]. The diagnosis of AML was based on morphological and phenotypic data. Subtypes according to the French- American-British classification were available for all the patients.

Patients were 21 males and 23 females. Age ranged from 21 to 65 years. The control group included 17 male and 27 females with no medical history of any type of cancer. Their ages ranged between 22 and 50 years. All patients and controls were analyzed for clinical and laboratory findings, including full history taking, clinical examination, routine laboratory investigations, $\mathrm{LDH}$, abdominal ultrasound for detection of organomegaly and lymphadenopathy. The patients were subjected as well to cytochemical, immunophenotypic and cytogenetic analysis to confirm the diagnosis and to divide the patients into their subtypes. Local institutional research board approval as well as written informed consent was obtained from all the participants before including them in the study.

All patients included in the study were treated according to the protocol of the nuclear medicine and oncology department, Cairo University, using ongoing induction and consolidation regimens for treatment of adult AML cases.

Induction of remission: Patients were subjected to 7-3 protocol [26] for induction of remission: Novantrone: $12 \mathrm{mg} / \mathrm{m}^{2}$, IV on day 1 and 3 . ARA - C: $100 \mathrm{mg} / \mathrm{m}^{2}$, continuous IV infusion, from day I-7. If remission is not achieved, this protocol was repeated again. If no or minimal response, patients were shifted to high dose chemotherapy. Induction therapy for acute promyelocytic leukemia (PML) included oral administration of all-trans-retinoic acid (ATRA) $45 \mathrm{mg} / \mathrm{m}^{2} /$ day until induces remission.

Consolidation [27]: High-dose ARA-C for 4 cycles. ARA-C: $2 \mathrm{~g} / \mathrm{m}^{2}$, over 2 hour's infusions, every 12 hours on days 1-4. Significant association to relapse-free survival and overall survival were estimated for studied genes at a median follow-up of 18 months.

Complete remission (CR) was defined as recovery of morphologically normal BM and peripheral blood cells with white cell counts $\geq 1,500 / L$, and platelets $\geq 100,000 / L$, less than $5 \%$ BM blasts and no evidence of extramedullary leukemia. Relapse was defined by $\geq 5 \%$ BM or peripheral blood blasts, or development of extramedullary leukemia in patients with previously documented CR. Relapse-free survival (RFS) was measured from the date of CR until the date of relapse or death [28]. 


\section{Collection and Processing Of Samples}

Gene expression was analyzed using quantitative real-time RT-PCR. Three $\mathrm{ml}$ of peripheral blood (of AML cases) and bone marrow samples (of control group) were collected on sterile ethelenediaminetetraacetic acid (EDTA) vacutainers. Mononuclear cells were enriched by Ficoll-Hypaque gradient and total RNA was extracted from freshly separated cells using Qiagen RNeasy mini spin column (RNeasy mini kit, Qiagen, Valencia, CA, USA) according to the manufacturer instructions.

Quantitative real-time RT-PCR assay was performed for estimation of $B A A L C$ and $E R G$ expression. BAALC and ERG mRNA expression levels were estimated from the corresponding genespecific calibration curves. The level GAPDH expression was measured for each sample using GAPDH standard curve.

\section{DNA Synthesis and Real-Time PCR Quantitation of BAALC and ERG MRNA Expression}

One microgram of the total RNA was transcribed into cDNA using random hexamers (Highcapacity cDNA kit; Applied Biosystems). An aliquot of the cDNA was used for quantitative PCR amplification by Gene Amp 7500 Sequence Detection System (Applied Biosystems), using $50 \mu$ l reaction mix containing $5 \mu \mathrm{l}$ cDNA, $25 \mu \mathrm{l}$ TaqMan Universal PCR master mix, $2.5 \mu$ l primer-probe mix using the following primers and probes:

BAALC (F): 5'-GCCCTCTGACCCAGAAACAG-3', BAALC (R): 5'-'CTTTTGCAGGCATTCTCTTAGCA-3', BAALC Probe: FAM-5'CTCTTTTAGCCTCTGTGGTCTGAAGGCCAT-3'TMRA.

ERG (F): 5'-AACGAGCGCAGAGTTATCGT-3', ERG (R): 5'-GTGAGCCTCTGGAAGTCGTC-3', ERG probe: FAM-5'-GGAGTACAGACCATGTGCGGCAGTG-3'TMRA

GAPDH (F): 5'-GAAGGTGAAGGTCGGAGTC-3', GAPDH (R): 5'- GAAGATGGTGATGGGATTTC -3, GAPDH probe: FAM-5

-CAAGCTTCCCGTTCTCAGCC-3'-TMRA and $17.5 \mu \mathrm{l}$ $\mathrm{H}_{2} \mathrm{O}$.

The thermal cycling conditions included: 10 min at $95^{\circ} \mathrm{C}$ followed by 45 cycles of denaturation for $15 \mathrm{~min}$ at $95^{\circ} \mathrm{C}$, annealing/extension at $60^{\circ} \mathrm{C}$ for $1 \mathrm{~min}$. A negative control ( $5 \mu$ l water instead of cDNA) was included in every TaqMan plate. The results were presented as the relative quantification levels of $B A A L C$ and $E R G$ in relation to the internal control GAPDH using the comparative cycle threshold (CT) method $\left(2^{-\Delta \Lambda} \mathrm{CT}\right)$. The cycle number difference e.g $\left(\triangle \mathrm{C}_{\mathrm{T}}=\mathrm{GAPDH}-B A A L C\right)$, was estimated for each case then $2^{-\Delta \Delta} \mathrm{CT}$ was calculated.

The threshold cycle data $(\mathrm{Ct})$ and baselines were determined using auto settings. The relative quantification of $B A A L C$ and $E R G$ expression was calculated using the comparative CT method (2$\triangle \triangle C T$ ) where $\triangle \triangle C T$ is the difference of $\triangle C T$ value between leukemia and the control $(\Delta \Delta \mathrm{CT}=\Delta \mathrm{CT}$ leukemia gene $-\Delta \mathrm{CT}$ control gene), and $\Delta \mathrm{CT}$ is the difference of CT value between the target (gene) and endogenous reference $(\mathrm{GAPDH})$ gene $(\triangle \mathrm{CT}=\mathrm{CT}$ Target gene - GAPDH gene).

\section{Statistics}

A pre-designed SPSS (Statistical Package for Social Science Version 17) file was used for data entry and analysis. The following tests were used: both unpaired and paired $\mathrm{t}$ - test, with $95 \%$ confidence intervals $(95 \% \mathrm{Cl})$, comparison of nonparametric quantitative data in two different groups using their mean rank performed by MannWhitney (Z). Chi-square was used for comparison of qualitative variables. Patients with expression values greater than the median of all samples were classified as high $B A A L C$ expression. ERG overexpression was defined as transcript level greater than the $75^{\text {th }}$ percentile of all measurements. Correlation between various variables was done using Pearson moment correlation equation for linear relation. $P$ value less than 0.05 was considered statistically significant and less than 0.01 was considered highly statistically significant.

No pre-study power calculation was performed. However, based on the number of subjects and controls included in this study, the sample size provides $95.5 \%$ power to detect a minimal difference of $9.0 \%$ with an alpha level of $0.05 "$.

\section{Results}

The present study was carried out on 44 patients with denovo AML, as well as 44 age and sex matched controls. The clinical and demographic data of the studied groups revealed no statistically significant differences between the 2 studied groups. The results of immunophenotyping and cytogenetics were obtained from the main laboratory of Kasr Alainy hospital. We selected the cases of $\mathrm{M} 2$ with $\mathrm{t}(8 ; 21)$, M3 with $t(15 ; 17)$, and M4 with inversion 16, and M5 with $t(9 ; 11)$. While cytogenetic results of $M 1$ cases were not available. Twelve patients $(27.2 \%)$ achieved complete remission following consolidation chemotherapy while 32 patients $(72.8 \%)$ did not. The overall survival of the patients ranged between 2 and 
18 months. Relapse-free survival ranged between 0 and 18 months.

$B A A L C$ was expressed in $36(81.82 \%)$ of $A M L$ cases versus $10(22.72 \%)$ of the control group which was highly statistically significant $(P<0.001)$. While $E R G$ was positive in $39(88.64 \%)$ of cases and 8 $(18.18 \%)$ of controls and that was also highly statistically significant $(P<0.001)$. The distribution of the positive cases among $F A B$ subtypes were as follows:

For BAALC gene positive cases, 14/17 patients $(82 \%)$ were $M 1,5 / 7$ patients $(71 \%)$ were $M 2$, $9 / 10$ patients $(90 \%)$ were $\mathrm{M} 3,4 / 5$ patients $(80 \%)$ were M4, $4 / 5$ patients $(80 \%)$ were M5.

For ERG gene positive cases, $16 / 17$ patients (94\%) were $M 1,5 / 7$ patients $(71 \%)$ were $M 2,10 / 10$ patients $(100 \%)$ were $M 3,4 / 5$ patients $(80 \%)$ were M4, $4 / 5$ patients $(80 \%)$ were M5.

The real-time results of the studied genes expressed as CT were summarized in Table 1.

Table 1: Results of $\triangle C T$ of $B A A L C$ and $E R G$ genes in patients and controls

\begin{tabular}{lccccc}
\hline & \multicolumn{2}{c}{ Patients (44) } & \multicolumn{2}{c}{ Controls (44) } & P value \\
\hline & Range & Mean \pm SD & Range & Mean \pm SD & \\
\hline BAALC & $26-45.5$ & $35 \pm 3.8$ & $37.8-49.5$ & $42.1 \pm 8.2$ & $0.045(\mathrm{~S})$ \\
\hline ERG & $32.7-46.6$ & $39.7 \pm 2.6$ & $39.8-42.6$ & $41.8 \pm 1.1$ & $0.064(\mathrm{NS})$ \\
\hline GADPH & $26.9-46$ & $32.6 \pm 1.6$ & $29.2-40.1$ & $33.3 \pm 3.4$ & $0.65(\mathrm{NS})$ \\
\hline
\end{tabular}

The lower values of $\mathrm{CT}$ in $\mathrm{AML}$ cases compared to $C T$ values in controls mean higher levels of BAALC and ERG genes in the cases as the numerical value of the $C T$ is inversely related to the amount of amplicon in the reaction.

Follow-up of the patients revealed 12 cases of $\mathrm{CR}$ and 32 with the unfavorable outcome; 17 showed partial recovery (PR), 8 cases relapsed and 7 patients died.

Correlations between $B A A L C$ and $E R G$ genes expression and other prognostic factors and treatment outcome were summarized in Table 2. Highly significant correlation was detected between positive genes expression and the presence of bulky tumor and organomegaly.

Table 2: Correlation between the results of BAALC and ERG genes expression and prognostic factors in patients

\begin{tabular}{|c|c|c|c|c|}
\hline & \multicolumn{2}{|c|}{$B A A L C$} & \multicolumn{2}{|r|}{$E R G$} \\
\hline & $r$ & $\mathbf{p}$ & $r$ & $\mathbf{p}$ \\
\hline$\overline{\text { Age }}$ & 0.06 & $0.07[\mathrm{NS}]$ & 0.06 & 0.07 [NS] \\
\hline Sex & 0.06 & 0.41 [NS] & 0.08 & 0.34 [NS] \\
\hline Organomegaly & 0.56 & $\mathrm{P}<0.001[\mathrm{HS}]$ & 0.55 & $\mathrm{P}<0.001[\mathrm{HS}]$ \\
\hline Presence of bulky tumor & 0.73 & $P<0.001[\mathrm{HS}]$ & 0.63 & $\mathrm{P}<0.001[\mathrm{HS}]$ \\
\hline High LDH level & 0.03 & 0.066 [NS] & 0.03 & 0.08 [NS] \\
\hline
\end{tabular}

The levels of each gene were expressed as 2 ${ }^{\triangle \Delta}$ CTi.e.number of fold increased above the mean level of the control group. Patients were divided into two groups according to these levels (high and low) as described previously in a statistic paragraph. BAALC levels median and range were 1479.8 (220.8-7550.2) for high levels group and 10.1 (0.13-54.9) for low levels group. While levels of ERG were 425.5 (27$1985)$ and 2.44 (0.021-8.17) for high and low levels groups respectively. Association of BAALC and ERG expression levels with clinical characteristics were summarized in Table 3.

Table 3: Association of BAALC and ERG expression levels with clinical characteristics

\begin{tabular}{|c|c|c|c|c|c|c|}
\hline & \multicolumn{3}{|c|}{$\begin{array}{c}\text { BAALC expression } \\
(\mathrm{N}=36 \text { patients })\end{array}$} & \multicolumn{3}{|c|}{$\begin{array}{l}\text { ERG expression } \\
\text { ( } \mathrm{N}=39 \text { patients) }\end{array}$} \\
\hline $\begin{array}{l}-\mathrm{No} \\
-\%\end{array}$ & $\begin{array}{l}\text { High } \\
24 \\
66.7\end{array}$ & $\begin{array}{c}\text { Low } \\
12 \\
33.3\end{array}$ & $P$ value & $\begin{array}{l}\text { High } \\
24 \\
61.5\end{array}$ & $\begin{array}{c}\text { Low } \\
15 \\
38.5\end{array}$ & $P$ value \\
\hline -Age (years) & & & & & & \\
\hline $\begin{array}{l}\text { Median } \\
\text { Range }\end{array}$ & $\begin{array}{r}42 \\
20-62\end{array}$ & $\begin{array}{r}44 \\
21-65\end{array}$ & 0.65 (NS) & $\begin{array}{c}43 \\
20-58\end{array}$ & $\begin{array}{c}48 \\
21-65\end{array}$ & 0.76 (NS) \\
\hline $\begin{array}{l}\text {-FAB classification } \\
\text { M1 } \\
\text { M2 } \\
\text { M3 } \\
\text { M4 } \\
\text { M5 }\end{array}$ & $\begin{array}{l}9 \\
3 \\
6 \\
3 \\
3\end{array}$ & $\begin{array}{l}5 \\
2 \\
3 \\
1 \\
1\end{array}$ & 0.54 (NS) & $\begin{array}{l}3 \\
9 \\
6 \\
3 \\
3\end{array}$ & $\begin{array}{l}2 \\
7 \\
4 \\
1 \\
1\end{array}$ & 0.59 (NS) \\
\hline $\begin{array}{l}\text {-Leucocyte count } \\
\text { Median } \\
\text { Range }\end{array}$ & $\begin{array}{r}21.9 \\
3.0-32\end{array}$ & $\begin{array}{c}13.6 \\
3.2-24\end{array}$ & $0.03(\mathrm{~S})$ & $\begin{array}{r}22.4 \\
3.2-32\end{array}$ & $\begin{array}{c}12.1 \\
3-20.5\end{array}$ & $0.02(\mathrm{~S})$ \\
\hline $\begin{array}{l}-\mathrm{Hg} \text { level } \\
\text { Median } \\
\text { Range }\end{array}$ & $\begin{array}{r}7.5 \\
3.1-8.5\end{array}$ & $\begin{array}{c}8 \\
5.2-10\end{array}$ & 0.64 (NS) & $\begin{array}{c}7.8 \\
3.0-7.4\end{array}$ & $\begin{array}{c}8.9 \\
6.1-10.0\end{array}$ & 0.75 (NS) \\
\hline $\begin{array}{l}\text {-Platelet count } \\
\text { Median } \\
\text { Range }\end{array}$ & $\begin{array}{r}100 \\
30-110\end{array}$ & $\begin{array}{r}120 \\
36-130\end{array}$ & 0.73 (NS) & $\begin{array}{c}90 \\
32-100\end{array}$ & $\begin{array}{r}110 \\
36-135\end{array}$ & 0.56 (NS) \\
\hline $\begin{array}{l}\text {-BM blasts\% } \\
\text { Median } \\
\text { Range }\end{array}$ & $\begin{array}{c}85 \\
22-98\end{array}$ & $\begin{array}{c}80 \\
21-90\end{array}$ & $0.67(\mathrm{NS})$ & $\begin{array}{c}83 \\
21-96\end{array}$ & $\begin{array}{c}77 \\
20-89\end{array}$ & 0.43 (NS) \\
\hline $\begin{array}{l}\text {-Response to } \\
\text { treatment }\end{array}$ & 2 & 10 & $0.03(\mathrm{~S})$ & 3 & 9 & $0.04(\mathrm{~S})$ \\
\hline $\begin{array}{l}\text {-Relapse-free } \\
\text { survival }\end{array}$ & & & & & & \\
\hline Median(months) & 3 & 16 & $\begin{array}{c}\mathrm{P}<0.001 \\
\quad[\mathrm{HS}]\end{array}$ & 3 & 16 & $\begin{array}{c}\mathrm{P}<0.001 \\
{[\mathrm{HS}]}\end{array}$ \\
\hline Median (months) & 6 & 18 & $\begin{array}{c}\mathrm{P}<0.001 \\
{[\mathrm{HS}]}\end{array}$ & 6 & 18 & $\begin{array}{c}\mathrm{P}<0.001 \\
{[\mathrm{HS}]}\end{array}$ \\
\hline
\end{tabular}

There were statistically no significant differences between the 2 studied groups regarding the $B A A L C$ gene expression before and after treatment $(\mathrm{P}$ value $=0.86)$ or the $E R G$ gene expression before and after treatment $(P$ value $=0.75)($ Table 4$)$.

Table 4: Results of BAALC and ERG expression in patients before and after treatment

\begin{tabular}{ccccc}
\hline & \multicolumn{2}{c}{$B A A L C$} & \multicolumn{2}{c}{$E R G$} \\
\hline \multicolumn{2}{c}{ high } & low & high & low \\
\hline & & & & \\
Median & 1479.8 & 10.2 & 425.5 & 2.4 \\
Range & $220.7-7550.2$ & $0.13-54.9$ & $27.3-1985.9$ & $0.02-8.2$ \\
\hline
\end{tabular}

The multivariate regression test had revealed that $B A A L C$ and $E R G$ are independent risk factors for acute leukemia, because (Table5). Although we abolished the effect of bad prognostic factors (age > 60 years, high serum LDH and WBC levels, high bone marrow blast percentage, presence of a bulky tumor), still high levels of these genes are associated with lower CR, RFS, and shorter OS. 
Table 5: Multivariate regression analysis for BAALC and ERG expression with the prognostic markers

\begin{tabular}{llcccc}
\hline & Patients groups & OR & $\mathrm{HR}$ & $95 \% \mathrm{Cl}$ & $\mathrm{P}$ value \\
\hline -Complete & BAALC expression, high versus low & 4.3 & - & $3.5-9.7$ & $0.03(\mathrm{~S})$ \\
remission & $E R G$ expression, high versus low & 3.9 & - & $3.1-8.5$ & $0.04(\mathrm{~S})$ \\
& & & & & \\
-RFS & $B A A L C$ expression, high versus low & & 2.1 & $1.5-2.8$ & $0.02(\mathrm{~S})$ \\
& ERG expression, high versus low & & 1.5 & $1.1-2.7$ & $0.02(\mathrm{~S})$ \\
& & & & \\
-OS & BAALC expression, high versus low & & 2.2 & $1.7-3.5$ & $0.03(\mathrm{~S})$ \\
& ERG expression, high versus low & & 2.8 & $2.4-4.5$ & $0.04(\mathrm{~S})$ \\
\hline
\end{tabular}

\section{Discussion}

$B A A L C$ and $E R G$ are transcription factors involved in the process of hematopoiesis subsequently their deranged expression is associated with leukemogenesis and its prognosis. We estimated their levels in BM of normal individuals and peripheral blood of leukemic cases as their expression is restricted to the progenitor cells in the BM and downregulated with cellular maturation. The present study revealed $36 / 44(81.82 \%)$ BAALC positive AML cases compared to $10 / 44(22.72 \%)$ of the control group $(\mathrm{P}<$ $0.001)$. While $E R G$ was positive in $39(88.64 \%)$ of cases and $8(18.18 \%)$ of controls and that was also highly significant $(P<0.001)$. Positive cases were associated with bulky tumor and organomegaly. That was higher than the incidence of $B A A L C$ detected by Balatzenko et al [29]; 53/91 (58.2\%).

High levels of BAALC and ERG were detected almost concomitantly in $54.5 \%$ of cases. They showed significant positive correlation to white cell counts. Marcucci et al. [19], also detected concomitant high BAALC and ERG levels in $25 \%$ of AML-NC cases with positive correlation to blast counts.

Eid et al., [25], detected high expression of $B A A L C$ in $70 \%$ of patients and its expression did not correlate with the clinical parameters of patients. $E R G$ was high in $33.3 \%$ of patients and its expression was associated with lower ages and higher white cell counts.

The distribution of positive cases and cases with high $B A A L C$ and $E R G$ among FAB subtypes did not show any significant difference. Subsequently, no association with their cytogenetic abnormalities was found. That was also concomitant with results of Eid et al, [25] but different from that of Baldus et al., 2006[10] who found a significant association between $B A A L C$ and $\mathrm{M} 0 / \mathrm{M} 1$.

Heuser et al. [30] have shown that BAALC expression hinders cell differentiation, but does not promote cell proliferation. They believed that for the onset of leukemia another factor must exist to promote uncontrolled proliferation.
As regard treatment outcome high levels of $B A A L C$ and ERG were associated with lower incidence of $C R(P=0.03$ and 0.04 respectively) and shorter RFS and OS $(\mathrm{P}<0.001)$.

Multivariable analysis demonstrated that $B A A L C$ and ERG genes over-expression are an independent predictor of low rate of CR, shorter RFS, and OS. These results are in consistent with Metzeler et al., 2009 [12], who found that high transcript levels of $E R G$ and $B A A L C$ were predictors for inferior OS and a lower rate of CRs. They also described significant positive correlations between the expression levels of the two genes and a third one (MN1). In agreement with these results, Baldus et al. 2003 [8], 2006 [10] demonstrated a significant association between high BAALC expression and resistance of $A M L$ to therapy and low CR. Moreover, they found high BAALC to be an independent predictor of relapse. Marcucci et al., 2005 [19] also demonstrated that increased $E R G$ expression was associated with poor prognosis in CN-AML.

Schwind et al., 2010 [31], found that expression levels of both BAALC and ERG were the only factors significantly associated with overall survival upon multivariable analysis.

In order to investigate the applicability of $B A A L C$ and ERG in the detection of MRD, we measured their levels again in patients achieved $C R$ for the first time. Although their levels decreased in each examined case but their reduction did not reach statistical significant difference while the cases showed normal morphological and cytogenetic examinations.

Weber et al., [32] correlated BAALC expression levels of the diagnostic samples with those of the first sample showing complete molecular remission (CMR) defined by NPM1 mutational status. They found, no significant difference of BAALC expression levels in those nine patients during treatment. However, 13 patients with BAALC overexpression at diagnosis showed a strong reduction in its mean expression levels at first CMR. Moreover, in four cases a molecular relapse was detected based on elevated BAALC expression levels within 37-149 days before morphological relapse. Conflicting results had appeared when they correlated $B A A L C$ expression levels with other mutated genes used in MRD detection.

Due to limited financial support, we could not estimate the changes in BAALC and ERG levels during the course of treatment and follow-up. Their levels might decrease gradually after CR. To overcome the previous conflicting results, larger scale researches must be done on AML cases to determine applicability and sensitivity of $B A A L C$ in the detection of MRD.

As regard $E R G$, the levels in $A M L$ cases did not differ significantly from theirs in normal BM. So the 
determination of cut-off value to detect MRD will not be applicable.

Further researches still needed to clarify the role of $B A A L C$ and $E R G$ in the pathogenesis of leukemia and their importance as targets for treatment of AML that could be promising due to their high incidence of expression in AML.

\section{References}

1. Mrozek K, Heerema NA, Bloomfield CD. Cytogenetics in acute leukemia. Blood Rev. 2004;18: 115-136.

http://dx.doi.org/10.1016/S0268-960X(03)00040-7

2. Fernandez HF, Sun Z, Yao X, Litzow MR, Luger SM, Paietta EM et al. Anthracycline dose intensification in acute myeloid leukemia N Engl J Med. 2009;361:1249-1259.

http://dx.doi.org/10.1056/NEJMoa0904544 PMid:19776406 PMCid:PMC4480917

3. Burnett AK, Hills RK, Milligan DW, Goldstone AH, Prentice AG, McMullin MF et al. Attempts to optimize induction and consolidation treatment in acute myeloid leukemia: Results of the MRC AML12 trial. J Clin Oncol. 2010;28:586-95.

http://dx.doi.org/10.1200/JCO.2009.22.9088 PMid:20038732

4. Slovak ML, Kopecky KJ, Cassileth PA. Karyotypic analysis predicts outcome of pre remission and post remission therapy in adult acute myeloid leukemia: a Southwest Oncology Group/Eastern Cooperative Oncology Group Study. Blood. 2000;96:4075-4083. PMid:11110676

5. Grimwade D, Walker H, Harrison G, Oliver F, Chatters S, Harrison CJ et al. Medical Research Council Adult Leukemia Working Party. The predictive value of hierarchical cytogenetic classification in older adults with acute myeloid leukemia (AML): analysis of 1065 patients entered into the United Kingdom Medical Research Council.AML11 trial. Blood. 2001;98:1312-1320. http://dx.doi.org/10.1182/blood.V98.5.1312 PMid:11520776

6. Bloomfield CD, Lawrence D, Byrd JC, Carroll A, Pettenati MJ, Tantravahi $R$ et al. Frequency of prolonged remission duration after high-dose cytarabine intensification in acute myeloid leukemia varies by cytogenetic. Cancer Res. 1998;4173-4179.

PMid:9751631

7. Scheijen B \& Griffin JD. Tyrosine kinase oncogenes in normal hematopoiesis and hematological disease. Oncogene. 2002;21: 3314-3333. http://dx.doi.org/10.1038/sj.onc.1205317 PMid:12032772

8. Baldus CD, Tanner SM, Kusewitt DF, Liyanarachchi S, Choi C, Caligiuri MA et al. BAALC, a novel marker of human hematopoietic progenitor cells. Exp Hematol. 2003;31(11):1051-6. PMid:14585369

9. Downing JR. AML1/CBFb transcription complex: its role in normal hematopoiesis and leukemia. Leukemia.2001;15:664-665. http://dx.doi.org/10.1038/sj.leu.2402035 PMid:11368373

10. Baldus CD, Burmeister T, Martus P, Schwartz S, Gökbuget N, Bloomfield CD, et al. BAALC expression and FLT3 internal tandem duplication mutations in acute myeloid leukemia patients with normal cytogenetics: prognostic implications. J Clin Oncol. 2006;24:790-797. http://dx.doi.org/10.1200/JCO.2005.01.6253 PMid:16418499

11. Langer C, Radmacher MD, Ruppert AS, Whitman SP, Paschka P, Mrózek K et al. Cancer and Leukemia Group B (CALGB). High BAALC expression associates with other molecular prognostic markers, poor outcome, and a distinct gene-expression signature in cytogenetically normal patients younger than 60 years with acute myeloid leukemia: a Cancer and Leukemia Group B (CALGB) study. Blood. 2008;111: 5371-5379.

http://dx.doi.org/10.1182/blood-2007-11-124958 PMid:18378853 PMCid:PMC2396728
12. Metzeler KH, Dufour A, Benthaus T, Hummel M, Sauerland MC, Heinecke A. ERG expression is an independent prognostic factor and allows refined risk stratification in cytogenetically norma acute myeloid leukemia: a comprehensive analysis of ERG, MN1, and BAALC transcript levels using oligonucleotide microarrays. J Clin Oncol. 2009;27: 5031-5038.

http://dx.doi.org/10.1200/JCO.2008.20.5328 PMid:19752345

13. Bienz M, Ludwig M, Leibundgut EO. Risk assessment in patients with acute myeloid leukemia and a normal karyotype. Clin Cancer Res. 2005;11:1416-24. http://dx.doi.org/10.1158/10780432.CCR-04-1552 PMid:15746041

14. Bing Xu, Guoshu Chen, Pengcheng Shi. ShRNA - Mediated BAALC knockdown affects proliferation and apoptosis in human acute myeloid leukemia cells. Hematology. 2012;17:35-40. http://dx.doi.org/10.1179/102453312X13221316477499 PMid:22549446

15. Austin JL, Leone G. BAALC, the human member of a novel mammalian neuroectoderm gene lineage, is implicated in hematopoiesis and acute leukemia. Proc Natl Acad Sci USA. 2001;98(24):13901-13906.

http://dx.doi.org/10.1073/pnas.241525498 PMid:11707601 PMCid:PMC61139

16. Tanner SM, Austin JL, Leone G, Rush LJ, Plass C, Heinonen K et al. BAALC expression predicts clinical outcome of de novo acute myeloid leukemia patients with normal cytogenetics: a Cancer and Leukemia Group B study. Blood. 2003;102:1613-1618. http://dx.doi.org/10.1182/blood-2003-02-0359 PMid:12750167

17. Taoudi S, Bee T, Hilton A, et al. ERG dependence distinguishes developmental control of hematopoietic stem cell maintenance from hematopoietic specification. Genes Dev. 2011;25: 251-62. http://dx.doi.org/10.1101/gad.2009211 PMid:21245161 PMCid:PMC3034900

18. Baldus CD, Liyanarchchi S, Mro'zek K, Auer H, Tanner SM, Guimond $\mathrm{M}$, et al. Acute myeloid leukemia with complex karyotypes and abnormal chromosome 21: amplification discloses overexpression of APP, ETS2 and ERG genes. Proceedings of the National Academy of Sciences of the United States of America. 2004;101:3915-3920. http://dx.doi.org/10.1073/pnas.0400272101 PMid:15007164 PMCid:PMC374344

19. Marcucci G, Baldus CD, Ruppert AS, Radmacher MD, Mrózek $\mathrm{K}$, Whitman SP et al. Overexpression of the ETS-related gene, ERG, predicts a worse outcome in acute myeloid leukemia with normal karyotype: a Cancer and Leukemia Group B study. J Clin Oncol. 2005;23: 9234-9242. http://dx.doi.org/10.1200/JCO.2005.03.6137 PMid:16275934

20. Baldus CD, Burmeister T, Martus P, Schwartz S, Gökbuget N, Bloomfield CD et al. High expression of the ETS transcription factor ERG predicts adverse outcome in acute T-lymphoblastic leukemia in adults. J Clin Oncol. 2006; 24: 4714-4720.

http://dx.doi.org/10.1200/JCO.2006.06.1580 PMid:16954520

21. Delattre O, Zucman J, Plougastel B, Desmaze C, Melot T, Peter $\mathrm{M}$ et al. Gene fusion with an ETS DNA-binding domain caused by chromosome translocation in human tumours. Nature. 1992;359:162-165. http://dx.doi.org/10.1038/359162a0 PMid: 1522903

22. Sorensen PH, Lessnick SL, Lopez-Terrada D, Liu XF, Triche TJ, Denny CT. A second Ewing's sarcoma translocation, $t(21 ; 22)$, fuses the EWS gene to another ETS-family transcription factor ERG. Nat Genet. 1994:6:146-151.

http://dx.doi.org/10.1038/ng0294-146 PMid:8162068

23. Shimizu K, Ichikawa H, Tojo A, Kaneko Y, Maseki N, Hayashi $Y$ et al. An ets-related gene, ERG, is rearranged in human myeloid leukemia with $\mathrm{t}(16 ; 21)$ chromosomal translocation. Proc Natl Acad Sci USA. 1993:90:10280-10284

http://dx.doi.org/10.1073/pnas.90.21.10280 PMid:8234289 PMCid:PMC47758

24. Panagopoulos I, Aman P, Fioretos T, Hoglund M, Johansson B, et al. Fusion of the FUS gene with ERG in acute myeloid leukemia with $\mathrm{t}(16 ; 21)(\mathrm{p} 11 ; \mathrm{q} 22)$. Genes Chromosomes Cancer. 1994;11:256-262. http://dx.doi.org/10.1002/gcc.2870110408 


\section{PMid:7533529}

25. Eid MA, Attia M, Abdou S, El-Shazly SF, Elahwal L, Farrag W et al. BAALC and ERG expression in acute myeloid leukemia with normal karyotype: impact on prognosis. International Journal of Laboratory Hematology. 2010;32:197-205. http://dx.doi.org/10.1111/j.1751-553X.2009.01168.x PMid:19555438

26. Vardiman JW, Harris NL, Brunning RD. The World Health Organization (WHO) classification of the myeloid neoplasms. Blood. 2002;100: 2292-2302. http://dx.doi.org/10.1182/blood-200204-1199 PMid:12239137

27. Preisler H, Davis RB, Kirshner J, Dupre E, Richards F 3rd, Hoagland $\mathrm{HC}$ et al. Comparison of three remission induction regimens and two postinduction strategies for the treatment of acute nonlymphocytic leukemia: a cancer and leukemia group B study. Blood. 1994;69:1441-1449.

28. Mayer RJ, Davis RB, Schiffer CA, Berg DT, Powell BL, Schulman $P$ et al. Intensive post remission chemotherapy in adults with acute myeloid leukemia. Cancer and Leukemia Group B. N Engl J Med. 1994;331:896-903.

http://dx.doi.org/10.1056/NEJM199410063311402 PMid:8078551

29. Balatzenko G, Stoimevov A, Guenova M, Nikolova V, Toshkov $\mathrm{S}$. Incidence of BAALC gene over-expression in acute myeloid leukemia subtypes as defined by the World Health Organization classification. Haematologica. 2008;93(s1):407.

30. Heuser M, Berg T, Kuchenbauer F, Lai CK, Park G, Fung S et al. Functional role of BAALC in leukemogenesis. Leukemia. 2012;26: 532-536. http://dx.doi.org/10.1038/leu.2011.228 PMid:21869843

31. Schwind S, Marcucci G, Maharry K, Radmacher MD, Mrózek K, Holland KB et al. BAALC and ERG expression levels are associated with outcome and distinct gene and microRNA expression profiles in older patients with de novo cytogenetically normal acute myeloid leukemia: a Cancer and Leukemia Group B study. Blood. 2010;116: 5660-5669.

http://dx.doi.org/10.1182/blood-2010-06-290536 PMid:20841507 PMCid:PMC3031412

32. Weber S, Alpermann T, Dicker F, Jeromin S, Nadarajah N, Eder C. BAALC expression: a suitable marker for prognostic risk stratification and detection of residual disease in cytogenetically normal acute myeloid leukemia. Blood Cancer Journal. 2014; 4: e173. http://dx.doi.org/10.1038/bcj.2013.71 PMid:24413067

PMCid:PMC3913940 